\title{
Incidence of different tumors in bovines
}

\begin{abstract}
The incidence of tumors in bovines is relatively increasing which undermine the productivity of animals. Cattle occupied the second place after dogs for incidence of tumors. A total of 59 samples suspected for neoplasia were collected in cattle (47 samples) and buffaloes (12 samples) during 2012-2014, out of which neoplasia were diagnosed in 57 samples. The tumors were classified based on histogenesis into tumors of epithelial origin, tumors of mesenchymal origin, mixed tumors and miscellaneous tumors, which constituted $54.38 \%, 42.09 \%, 1.75 \%$ and $1.75 \%$, respectively. The benign and malignant tumors constituted $56.14 \%$ and $43.86 \%$, respectively. The incidence was almost equal in male and female animals with $50.88 \%$ and $49.12 \%$, respectively. The incidence of tumors was high in cattle (78.95\%) than in buffaloes $(21.05 \%)$. The tumors affecting skin and soft tissues constituted more than $50 \%$ of the total bovine tumors examined. Among the different bovine tumors, the highest number of cases were those of papilloma (21.05\%) followed by squamous cell carcinoma $(17.54 \%)$, fibroma (17.54\%), lymphosarcoma (14.04\%) and adenoma (7.02\%). Two cases each of adenocarcinoma, melanoma and myxosarcoma were found, which constituted $3.51 \%$. Basal cell carcinoma, hemangioma, leiomyoma, leiomyosarcoma, mast cell tumor, fibroleiomyoma and adamantinoma were seen in one case each $(1.75 \%)$. In the present research, the findings revealed that the incidence of tumors affecting skin and soft tissues was highest in bovines when compared to other types of tumors.
\end{abstract}

Keywords: tumors, epithelial, mesenchymal, cattle, buffalo, skin, soft tissues, melanoma, myxosarcoma, adenocarcinoma, bovine tumors, female animals, carcinoma
Volume 2 Issue 4 - 2018

\author{
Shruthi PJ, Sujatha K, Srilatha CH, Rayulu VC \\ Department of Veterinary Pathology, Sri Venkateswara \\ Veterinary University, India
}

Correspondence: Sujatha K, Department of Veterinary Pathology, Sri Venkateswara Veterinary University, India, Email karamalasujatha@gmail.com

Received: June 15, 2018 | Published: July 18, 2018

\section{Introduction}

Tumour incidence in cattle is relatively increased; specialty literature indicating the second place, after dogs, for tumour incidence in bovines.Recently, the tumor incidence in bovines is relatively increasing. Cattle occupied the second place after dogs for incidence of all tumors. ${ }^{1}$ Tumors affecting skin and appendages form a major component of all neoplasms in veterinary practice. ${ }^{2}$ Among the skin tumors, bovine cutaneous papillomatosis and squamous cell carcinoma $(\mathrm{SqCC})$ are commonly diagnosed and economically important neoplasms in large animals. ${ }^{3-5} \mathrm{SqCC}$ is a common tumor among cattle in India affecting the horn and the eye ${ }^{6}$ and it constitutes $41.46 \% .^{7}$ Horn cancer affects approximately one percent of bullock population in India. ${ }^{8}$ Lymphoid tumors comprise one of the most common groups of tumors in domestic animals. Lymphosarcoma is expressed as a specific multicentric form in calves up to six months of age (sporadic) and in adult cattle (enzootic); and as thymic form in young cattle. ${ }^{10}$ Among the internal body organs of bovines, tumors are commonly diagnosed in adrenal glands, uterus and occasionally in liver, gallbladder, ovary, kidney and heart. ${ }^{9}$ Out of the total carcasses that are rejected at slaughter house, tumor affected carcasses account for $41.1 \%$ and the most frequent localization of tumors was found in urinary bladder $(50.9 \%)$, followed by third eyelid and skin $(20 \%$ and $15.7 \%$, respectively). ${ }^{11}$

\section{Materials and methods}

The materials for present study included the samples suspected for neoplasia of bovine origin submitted to the Department of Veterinary Pathology, College of Veterinary Science, Tirupati by the Department of Veterinary Surgery and Radiology and Veterinary Dispensaries in and around Tirupati. Samples were also collected from animals necropsied in the Department of Veterinary Pathology. Particulars like breed, sex, location, shape, colour and consistency of growths were recorded. Representative tissue samples collected were fixed in 10 percent neutral buffered formalin and processed routinely for histopathological examination. Sections of 4-6 $\mu$ thickness were made and stained with Haematoxylin and Eosin. Special staining techniques with Masson's Trichome, VanGieson, Mayer's Mucicarmine and Toluidine blue stains were employed wherever necessary. ${ }^{12,13}$

\section{Results}

Out of the 59 samples (cattle 47 samples and buffaloes 12 samples) examined, neoplasia was diagnosed in 57 samples based on histopathology. Hyperplasia and lymphadenitis of lymph nodes $(2 / 57)$ accounted for the remaining non neoplastic cases. The tumors were classified based on histogenesis into tumors of epithelial origin, tumors of mesenchymal origin, mixed tumors and miscellaneous tumors (Table 1) which constituted $54.38 \%, 42.09 \%, 1.75 \%$ and $1.75 \%$, respectively (Figure 1). The incidence of benign (32/57) and malignant $(25 / 57)$ tumors was $56.14 \%$ and $43.86 \%$, respectively (Table 2). The incidence was almost equal in male (29/57) and female (28/57) animals with $50.88 \%$ and $49.12 \%$, respectively. The incidence of tumors was higher in cattle (78.95\%) than in buffaloes $(21.05 \%)$. The highest number of cases were papilloma $(12 / 57)$ followed by squamous cell carcinoma (10/57), fibroma (10/57), lymphosarcoma (8/57), adenoma (4/57), adenocarcinoma (2/57), melanoma (2/57) and myxoma (2/57) and the incidence was $21.05 \%, 17.54 \%, 17.54 \%$, $14.04 \%, 7.02 \%, 3.51 \%, 3.51 \%$ and $3.51 \%$, respectively (Table 1) (Figure 2). Basal cell carcinoma, hemangioma, leiomyoma, leiomyosarcoma, mast cell tumor, fibroleiomyoma and adamantinoma were seen in one case each $(1.75 \%)$. 


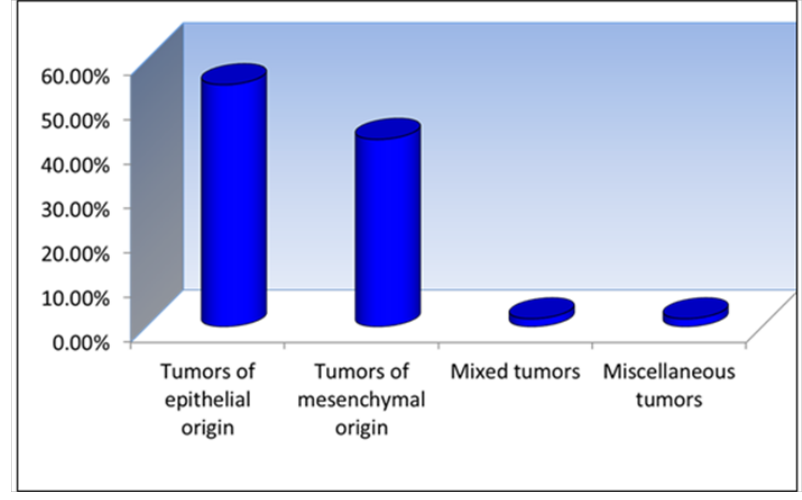

Figure I Incidence of bovine tumors.

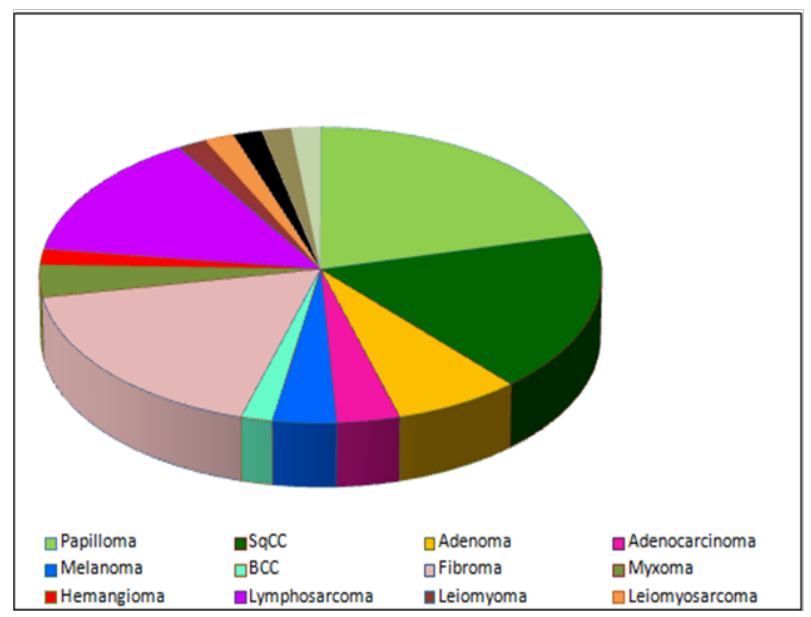

Figure 2 Prevalence of different bovine tumors.

Table I Incidence of bovine neoplasms

\begin{tabular}{llllll}
\hline S. No & Type of tumor & M & F & TOTAL & $\%$ \\
\hline I & Tumors of epithelial origin & & & \\
1 & Papilloma & 6 & 6 & 12 & 21.05 \\
2 & $\begin{array}{l}\text { Squamous } \\
\text { carcinoma }\end{array}$ & 4 & 6 & 10 & 17.54 \\
3 & Adenoma & 1 & 3 & 4 & 7.02 \\
4 & Adenocarcinoma & 2 & 0 & 2 & 3.51 \\
5 & Melanoma & 2 & 0 & 2 & 3.51 \\
6 & $\begin{array}{l}\text { Basal } \\
\text { carcinoma }\end{array}$ & 1 & 0 & 1 & 1.75 \\
II & Tumors of mesenchymal origin & & & \\
1 & Fibroma & 5 & 5 & 10 & 17.54 \\
2 & Myxosarcoma & 0 & 2 & 2 & 3.51 \\
3 & Hemangioma & 1 & 0 & 1 & 1.75 \\
4 & Lymphosarcoma & 6 & 2 & 8 & 14.04 \\
\hline
\end{tabular}

\begin{tabular}{llllll}
\hline S. No & Type of tumor & M & F & TOTAL & $\%$ \\
\hline 5 & Leiomyoma & 0 & 1 & 1 & 1.75 \\
6 & Leiomyosarcoma & 0 & 1 & 1 & 1.75 \\
7 & Mast cell tumor & 1 & 0 & 1 & 1.75 \\
III & Mixed tumors & & & & \\
& & 0 & 1 & 1 & 1.75 \\
1 & Fibroleiomyoma & 0 & & & \\
IV & Miscellaneous tumors & 1 & 1 & 1.75 \\
1 & Adamantinoma & 0 & 28 & 57 & 100 \\
\hline
\end{tabular}

Table 2 Incidence of different benign and malignant tumors in cattle and buffaloes

\begin{tabular}{|c|c|c|c|c|}
\hline S.NO. & Type of tumor & Cattle & Buffaloes & Total \\
\hline I & Benign tumors & & & \\
\hline 1 & Papilloma & 10 & 2 & 12 \\
\hline 2 & Adenoma & 3 & 1 & 4 \\
\hline 3 & Melanoma & 2 & 0 & 2 \\
\hline 4 & Fibroma & 8 & 2 & 10 \\
\hline 5 & Hemangioma & 1 & 0 & 1 \\
\hline 6 & Leiomyoma & 1 & 0 & 1 \\
\hline 7 & Mastocytoma & 1 & 0 & 1 \\
\hline \multirow[t]{2}{*}{8} & Fibroleiomyoma & 0 & 1 & 1 \\
\hline & Total & 26 & 6 & 32 \\
\hline II & Malignant Tumors & & & \\
\hline 1 & Squamous cell carcinoma & 7 & 2 & 10 \\
\hline 2 & Adenocarcinoma & 2 & 0 & 2 \\
\hline 3 & Basal cell carcinoma & 1 & 0 & 1 \\
\hline 4 & Myxosarcoma & 1 & 1 & 2 \\
\hline 5 & Lymphosarcoma & 8 & 0 & 8 \\
\hline 6 & Leiomyosarcoma & 0 & 1 & 1 \\
\hline \multirow[t]{2}{*}{7} & Adamantinoma & 0 & 1 & 1 \\
\hline & Total & 19 & 6 & 25 \\
\hline
\end{tabular}

\section{Discussion}

The present work was carried out on 59 neoplasia suspected samples collected during 2010 to 2014 in cattle and buffaloes. Out of the 59 samples examined, neoplasia was diagnosed in 57 samples based on cytology and histopathology. Hyperplasia and lymphadenitis of lymph nodes (2/57) accounted for the remaining non-neoplastic cases. Similarly, Dukes et al. (1982) observed neoplasia in 1370 cases out of 1535 suspected neoplasia cases in bovines and the remaining 165 cases were a mixture of inflammatory conditions. In the present study, the bovine tumors were classified based on histogenesis into tumors of epithelial origin $(54.38 \%)$, tumors of mesenchymal origin $(42.09 \%)$, mixed tumors $(1.75 \%)$ and miscellaneous tumors 
$(1.75 \%)$. The incidence of epithelial tumors was higher than the mesenchymal tumors. In contrary to the present study, ${ }^{14,15}$ observed the high incidence of mesenchymal tumors, with lymphosarcoma being the most common tumor. The percentage of benign tumors was higher $(56.14 \%)$ than that of the malignant tumors (43.08\%). Among the benign tumors, high incidence was that of papilloma $(21.05 \%)$ followed by fibroma (17.54\%) and among the malignant tumors, high incidence was that of SqCC (17.54\%). In contrary, Marosfoi et al. (2008) reported that the incidence of malignant tumors was higher than that of the benign tumors in slaughtered bovines $(85.71 \%)$, out of which $\mathrm{SqCC}$ constituted $71.43 \%$. The incidence of tumors was higher in cattle $(78.95 \%)$ than in buffaloes $(21.05 \%)$. Accordingly, ${ }^{16}$ observed the highest incidence in cattle $(87.95 \%)$ than in buffaloes $(2.82 \%)$, but ${ }^{17}$ reported high incidence in buffaloes $(6.67 \%)$ than in cattle (3.33\%). The present study revealed almost equal incidence of tumors in male and female bovines with $50.88 \%$ and $49.12 \%$, respectively. In contrary, ${ }^{16}$ observed the high incidence in male animals $(77.7 \%)$ than in female animals $(22.3 \%)$. The present research revealed that the incidence of tumors affecting skin and soft tissues was more in bovines compared to other tumors.

\section{Acknowledgements}

None.

\section{Conflict of interest}

The author declares there is no conflict of interest.

\section{References}

1. Marosfoi L, Baba AI, Catoi C. Morphological Study of Bovine Tumors. Bulletin of the University of Agricultural Sciences \& Veterinary. 2009;66(1):147.

2. Goldschmidt MH, Hendrick MJ. Tumors of the skin and soft tissues. In: Tumors in domestic animals, Meuten DJ editor. $4^{\text {th }}$ edition. Blackwell publishing company, Iowa; 2002. p. 45-119.

3. Meuten DJ. Tumours of the Haemolymphatic System. Tumours in Domestic Animals. $4^{\text {th }}$ edition. Iowa State Press, Ames. 2002. p.151156.

4. Ozsoy SY, Ozyildiz Z, Güzel M. Clinical, Pathological and Immunohistochemical Findings of Bovine Cutaneous Papillomatosis.
Ankara Universitesi Veteriner Fakultesi Dergisi. 2011;58:161-165.

5. Tan MT, Yildirim Y, Sozmen M, et al. A Histopathological, Immunohistochemical and Molecular Study of Cutaneous Bovine Papillomatosis. Kafkas Universitesi Veteriner Fakultesi Dergisi. 2012;18(5):739-744.

6. Sastry GA. Neoplasms. In: Veterinary Pathology. $6^{\text {th }}$ edition. CBS Publishers and Distributors, Delhi; 1983. p. 247-249.

7. Somvanshi R. Horn cancer in Indian cattle. Veterinary Bulletein. 1991;61:901-910.

8. Udharwar SV, Aher VD, Yadav GU, et al. Study on incidence, predisposing factors, symptomatology and treatment of horn cancer in bovine with special reference to surgery and chemotherapy. Veterinary World. 2008;1(1):7-9.

9. Davis CL, Shalkop WT. Tumors. In: Animal Diseases, part of agriculture series. 1956.

10. Moulton JE. Tumors of the skin and soft tissues. In: Tumors in domestic animals. $2^{\text {nd }}$ edition, University of California Press. Berkeley, Los Angeles, London; 1978. p. 16-70.

11. Pinto C, Geraldes M, Medeiros F. Slaughterhouse Monitoring of Cattle Neoplasias on Sao Miguel Island - Azores. Épidémiologie et Santé Animale (Epidemiology and Animal Health). 1977. p. 31-32.

12. Luna LG. Manual of Histologic Staining Methods of the Armed Forces. Institute of Pathology, $3^{\text {rd }}$ edition. The Blakiston Div., McGraw-Hill Book company, New York-Toronto. 1968.

13. Bancroft DJ, Cook CH. Manual of Histological Techniques and their Diagnostic Application. Churchill Livingstone, Medical Division of Longman Group UK Limited. 1994. p. 297-230.

14. Plummer. Tumors from domesticated animals. Canadian Journal of Comparative Medicine. 1956;20(7):239-251.

15. Dukes TW, Bundza A, Corner AH. Bovine Neoplasms Encountered in Canadian Slaughterhouses: a Summary. Can Vet J. 1982;23(1): 28-30.

16. Degloorkar NM, Moregaonkar SD, Deshpande BB. Neoplasms in domestic animals at Parbhani. Indian Journal of Veterinary Pathology. 1992;16(2):106-107.

17. Siva Kumar S, Pawde AM, Singh GR. Occurrence of neoplasms in domestic animals: A study of 60 cases. Indian Journal of Veterinary Pathology. 2004;28(1):70-72. 